\title{
Benign Pericytic Neoplasm
}

National Cancer Institute

\section{Source}

National Cancer Institute. Benign Pericytic Neoplasm. NCI Thesaurus. Code C6529.

A benign mesenchymal neoplasm arising from the perivascular cells of the connective and soft tissues. It is characterized by the presence of pericytes that grow in a circumferential pattern around vessels. 